\title{
Developing Attitude Scale, Reliability and Validity for Pre-Service Teachers towards Drama Lesson
}

\author{
Özkan Çelik ${ }^{1}$, Hafife Bozdemir ${ }^{2}$, Gökhan Uyanık ${ }^{2}$ \\ ${ }^{1}$ Muğla Sitkı Koçman University, Turkey \\ ${ }^{2}$ Kastamonu University, Turkey \\ Correspondence: Gökhan Uyanık, Kastamonu University, Turkey.
}

Received: October 12, 2016

doi:10.11114/jets.v4i12.1919
Accepted: November 2, $2016 \quad$ Online Published: November 21, 2016

URL: http://dx.doi.org/10.11114/jets.v4i12.1919

\begin{abstract}
The purpose of this study is to develop an attitude scale for pre-service teachers towards drama lesson. Survey model was used in study. The sample of study consisted of 258 pre-service teachers. "Attitude scale towards drama lesson for pre-service teachers" was developed and used as data collection tool. Exploratory and confirmatory factor analyses were used to provide evidence for construct validity of scale. For factor analysis, SPSS 19.0 statistical package software was used and Kaiser Meyer Olkin test (KMO) and Bartlett Sphericity test methods were used to determine suitability of data to principal component analysis. In confirmatory factor analysis, suitability of model which came out in exploratory factor analysis was checked out. Lisrel 8.7 package software was used in this process and it was benefited from the values of chi-square $\left(\chi^{2}\right)$, Degrees of Freedom (df), and Root-Mean-Square Error of Approximation (RMSEA). Drama experts' opinions were taken in order to ensure content validity. In conclusion, the final form of scale which consisted of 31 items was obtained and Cronbach alpha $(\mathrm{Cr} \alpha)$ value was calculated to get internal consistency coefficient. This calculated value was determined as .965 .
\end{abstract}

Keywords: drama, pre-service teachers, scale development, attitude

\section{Introduction}

With the current developments, there is a passing from teacher-centered education environment that teacher guided students to student-centered education environment that students are active and responsible for their learning. With this passing, the importance of methods that provides active participation in learning process increases gradually. One of the methods that provide active participation is drama. Drama methods might include other methods according to determined content. Drama is an efficient method that contains learning types such as experience-based learning, learning with action, active learning, learning via interaction, social learning, learning by discussing, learning by discovering, emotional learning, learning by establishing cooperation and concept learning (Önder, 2003). Drama takes part in many levels of education environments methodically from pre-school to elementary school, from secondary school to university.

\subsection{Drama in Education}

Drama is an art form in which people perform actions such as reflecting the human condition, playing a role, transforming to someone or something (Taylor, 2000). Students and teachers actively regenerate their perceptions regarding to world and humans by playing role in drama. Moreover, they deepen and expand their understandings about human except their roles (McNaughton, 2004). Teacher and all class learn from each other by sharing (Prendiville \& Toye, 2007). Students are both participants and observers. So they interact each other and configure their reactions and actions about the roles that was created unrealistically (Andersen, 2004). Drama processes provide opportunities to explain their reactions about students' class status through writing and dialogue and allow them to focus these reactions privately.

With the passing of time, students' reactions and thoughts expand and are shared with other students. Teachers and students are allowed to create context that they play their reactions in cooperative learning environment (Crump \& Schneider, 2002). In drama processes, beside learning and socialization, in one hand drama enhances trust and respect according to someone; on the other hand drama emphasizes social suppressive power that comes with being a member 
of a group according to someone and develops communication and problem-solving skills for others. Other qualities that were gained with drama are being participant instead of passivity, forehandedness and being independent instead of being independent, maturation and democratization (San, 1990). Interactive learning and teaching environments can be created by using drama by oneself or in lessons to make the program more creative and interesting in school (Baldwin, 2009).

Creative drama in education prepares opportunities for students and paves the way for various interactions. It aims to be conscious of students to their bodies, feelings, thoughts and goings-on. When creative drama is used as a method in lessons, students can both learn the lessons' subjects effectively and also become skillful at compliance, trust, collaboration, critical thinking, creativity and communicating with others which are general purpose of education by participating in creative drama's background study (Aykaç \& Adıgüzel, 2011). Participants, who take part in creative drama activities must be ready to work within a group firstly, feel comfortable and safe and be ready to explore new and different ways to themselves. The group leader who will direct this type of activity must take education even a little on acting and dramatics (Can \& Cantürk-Günhan, 2009).

In literature regarding effectiveness of drama, there are a number of studies in different issues and different sample groups (Akınoğlu \& Akbaş, 2010; Altıkulaç \& Akhan, 2010; Arslan, Şahin, Şahin \& Akçay, 2011; Avcıŏlu, 2012; Aykaç \& Adıgüzel, 2011; Çam, Özkan \& Avinç, 2009; Çelen, Akar-Vural, 2009; Dorion, 2009; Gomez, 2010; Karadağ, Korkmaz \& Çalışkan, 2007; Kırmızı, 2007; Köseoğlu \& Ünlü, 2006; Nicholls \& Philip, 2012; Oğur \& Bağc1-Kılıç, 2005; Özbek \& Baturay, 2009; Şimşek, Topal, Maden \& Şahin, 2010; Wright, Diener \& Kemp, 2013; Yavuzer, 2012). Considering these studies, drama is a highly effective teaching and discipline method in education especially at preschool and primary school ages. Effectiveness of the methods that used in educational environments might be vary depending upon many different reasons. One of these variables is attitudes and interests of teachers towards lesson and method.

\subsection{Measuring Pre-Service Teachers'Attitude Towards Drama Lesson}

Beliefs of teachers about learning and teaching play an important role in increasing students' interests to lessons in all fields (Levitt, 2002). Positive attitudes of teachers who will achieve the goals in learning environments towards a lesson have an impact on students' learning opportunities and performances (Kim, 2011). In this regard, it is important to know pre-service teachers' attitudes towards drama lesson. Thus, it is possible to say that attitude is a psychological tendency and this tendency is expressed by evaluating a particular entity with positive or negative degree (Eagly \& Chaiken, 1993).

\subsection{Rationale and Purpose for This Study}

Teachers who are in leading position in drama process should direct, form and affect students' learning (Prendivill \& Toye, 2007). Therefore, being competent is so important that teachers are able to use drama actively in education. Accordingly, drama is a compulsory lesson in many departments of the university faculties. Attitudes of pre-service teachers towards drama lesson might give an idea about using drama in their careers effectively and efficiently. In this sense, there are many researches regarding attitudes towards drama lesson (Baş̧̧ \& Gündoğdu, 2011; Ceylan \& Ömeroğlu, 2011; Fenli, 2010; Ünal, 2004). Many researches aim at developing attitude scale towards drama lesson. These are attitude scale towards drama lesson (Adigüzel, 2006), attitude assessment scale towards drama in pre-school education (Ceylan \& Ömeroğlu, 2011), creative drama attitude scale (Okvuran, 2000) and drama lesson attitude scale in primary education (Ünal, 2004). Attitudes towards drama in different education levels were discussed in researches that were carried out (Akınoğlu \& Akbaş, 2010; Altıkulaç \& Akhan, 2010; Avcıŏlu, 2012; Aykaç \& Adıgüzel, 2011; Dorion, 2009; Gomez, 2010; Nicholls \& Philip, 2012; Wright, Diener \& Kemp, 2013; Yavuzer, 2012). It was not found out any scale which was aimed to determine pre-service teachers' attitudes towards drama lesson. Hence, the purpose of this study is to develop a scale to determine attitudes of pre-service teachers towards drama lesson.

\section{Method}

\subsection{Participant Characteristics}

This research was conducted in spring term of 2013-2014 academic years. Research population consisted of the students who were studied at Gazi University Faculty of Education, Kastamonu University Faculty of Education and department of pre-school teacher and classroom teacher education. Sample was determined with purposive sampling method and consists of 258 pre-service teachers who studied at 3rd and 4th grade level in these undergraduate programs.

\subsection{Sampling Procedures}

The research sample was chosen from $3^{\text {rd }}$ and $4^{\text {th }}$ year pre-service teachers because they took drama lessons at $3^{\text {rd }}$ and $4^{\text {th }}$ grade and have sufficient knowledge to practice in this field. Descriptive statistics regarding working group who carried out scale work can be seen in Table 1 . 
Table 1. Descriptive statistics of pre-service teachers in the participant group

\begin{tabular}{|c|c|c|c|c|c|}
\hline \multirow[b]{3}{*}{ University } & \multirow[b]{3}{*}{ Gender } & \multicolumn{4}{|c|}{ Department } \\
\hline & & \multicolumn{2}{|c|}{ Classroom Teacher Education } & \multicolumn{2}{|c|}{ Pre-School Teacher Education } \\
\hline & & $f$ & $\%$ & $f$ & $\%$ \\
\hline \multirow{2}{*}{ Gazi University } & Female & 106 & 41.09 & 35 & 13.57 \\
\hline & Male & 27 & 10,47 & 5 & 1.94 \\
\hline \multirow{2}{*}{ Kastamonu University } & Female & 45 & 17.44 & 13 & 5.04 \\
\hline & Male & 23 & 8.91 & 4 & 1.55 \\
\hline Total & & 201 & 77.9 & 57 & 22.1 \\
\hline
\end{tabular}

According to Table 1, working group consisted of 258 students, while $77.9 \%$ of them studied at undergraduate program of primary school teaching, $22.1 \%$ of these students studied at undergraduate program of preschool teaching.

\subsection{Research Design}

This section of the research consisted of survey model, population and sample, data collection device, implementation process and analysis of data.

In this study, survey model was used. According to Cohen \& Manion (2007), survey studies, like attitude studies, are the ideal research method that can be used for studies required broad participation sampling. "An attitude scale towards drama lesson for pre-service teachers" was developed and used as data collection tool.

Studies in scale development phase, to determine attitude levels of pre-service teachers towards drama lesson are stated below.

\subsection{Scale Development Phase}

Researchers did literature research regarding attitude and measuring with attitude scale and then they prepared a draft questionnaire consisted of 45 items as a result of examining of theoretical structure on this issue. Besides, scales whose validity and reliability studies were done and which are in literature related attitudes towards drama were examined by researchers and benefited from this scale forming the draft questionnaire and writing scale items. Prepared items were examined by drama experts, assessment and evaluation experts and language experts, 5 items were crossed out by achieving a consensus in accordance with expert recommendations and 40-questioned final draft was completed. While 20 items contain positive statement, 20 items contain negative statement. Items are rated in quinary Likert-type as Strongly Disagree (1), Disagree (2), Neutral (3), Agree (4) and Strongly Agree (5).

\subsection{Materials and Procedure}

In data analysis phase of attitude scale's development process towards drama lesson for pre-service teachers it was conducted to 271 pre-service teachers, after 13 scales which were filled inappropriately or uncompleted were removed and data analysis were carried out on 258 scales. Various analyses were carried out to provide evidence for reliability and validity of the scale. Exploratory and confirmatory factor analyses were used to provide evidence for construct validity. SPSS 19.0 statistical software package was used for factor analysis and Kaiser Meyer Olkin test (KMO) and Bartlett Sphericity test methods were used to determine the suitability of data to principal component analysis for factor analysis. Obtained factors were named by researchers by considering common characteristics of materials. In confirmatory factor analysis, sustainability of model which revealed in exploratory factor analysis was controlled. Within this period, LISREL 8.7 software package, Chi-square $\left(\chi^{2}\right)$, Degrees of Freedom (DF), and Root-Mean-Square Error of Approximation (RMSEA) vales were used.

Opinions of drama expert were taken in order to ensure content validity of developed scale. In conclusion, final form of scale which consists of 31 items was completed and Cronbach alpha $(\mathrm{Cr} \alpha)$ value was calculated to get internal consistency coefficient.

\section{Results}

This section includes the findings of research.

\subsection{Findings Regarding Validity}

Rotated Principal Component Analysis was used for construct validity analysis of developed attitude scale towards drama lesson. Suitability of obtained data to Principal Component Analysis was determined with Kaiser-Meyer-Olkin (KMO) coefficient and Bartlett Sphericity test values. As a result of implemented factor analysis, 9 items (1, 5, 14, 15, $20,29,32,34$, and 37) which were not suitable for scale's structure and loaded more than one dimension were removed from scale and it was continued with remaining 31 items. As a result of analysis, KMO value was calculated as .963 . Moreover, it was reached a finding that chi-square statistic test values, which was obtained as a result of Bartlett Sphericity test, were significant $\left(\chi^{2}=5738.89, \mathrm{df}=465, \mathrm{p}=.000\right)$. Eigenvalues for scale items can be seen in Scree Plot graph in Figure 1. 


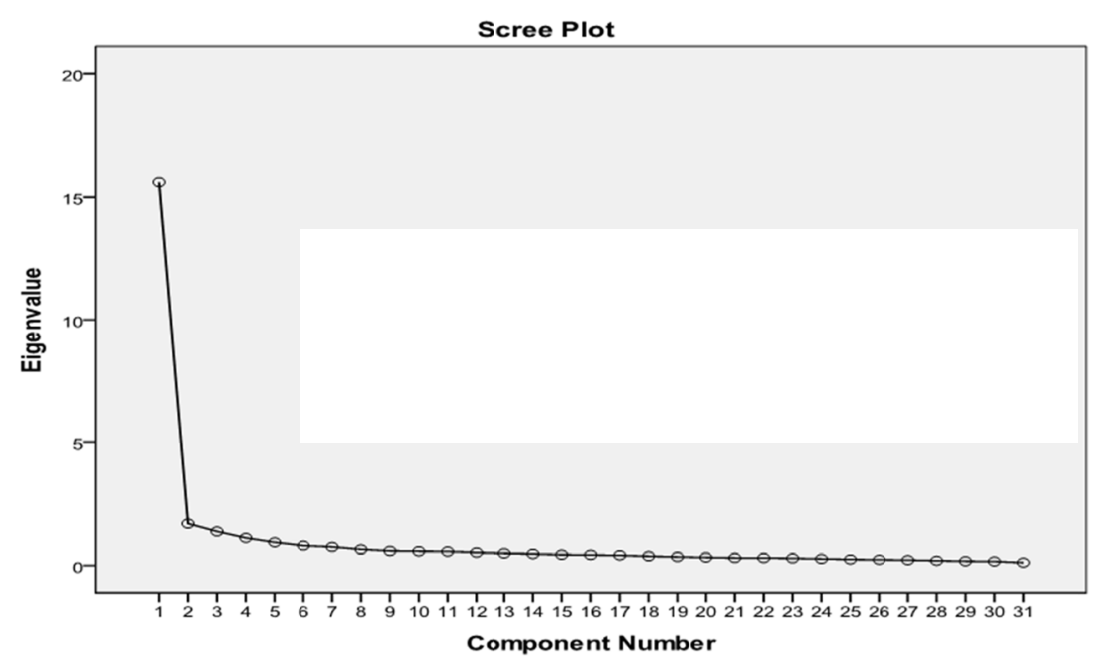

Figure 1. Eigenvalues for scale items

Factor analyses were made by using varimax method of vertical rotation methods and factor loads lower cut-off point was taken as .45. Exploratory factor analysis results belonging to remaining 31 items can be seen in Table 2 .

Table 2. Exploratory factor analysis values regarding factors belonging to "Attitude scale towards drama lesson for pre-service teachers" items.

\begin{tabular}{|c|c|c|c|c|}
\hline \multirow{2}{*}{ Items } & \multicolumn{4}{|c|}{ Factors } \\
\hline & F1 & F2 & F3 & F4 \\
\hline 24. I believe drama lessons develop my imagination. & .735 & & & \\
\hline 22. I think my self-confidence increases thanks to drama lessons. & .724 & & & \\
\hline 31. I think I will improve my ability of making quick decision thanks to drama lesson. & .717 & & & \\
\hline 9. I believe drama lesson affects my comprehension skill positively. & .706 & & & \\
\hline 28. I believe drama lesson improve my sense of responsibility. & .705 & & & \\
\hline 7. I think drama lesson will change my perspective on events. & .691 & & & \\
\hline 27. I believe drama lesson will improve my creative ability. & .690 & & & \\
\hline 6. I believe I know myself better thanks to drama lesson. & .686 & & & \\
\hline 2. I think drama lesson affects my communication skill positively. & .645 & & & \\
\hline 16. I can control my emotions better thanks to drama lesson. & .634 & & & \\
\hline 8. I think drama lesson contributes to my professional ability. & 600 & & & \\
\hline 23. I find drama lessons entertaining. & .592 & & & \\
\hline 26. I feel comforted after drama lessons. & .507 & & & \\
\hline 17. Drama lesson do not contribute to my education. & & .653 & & \\
\hline 12. I do not think drama lessons will improve my empathy ability. & & .643 & & \\
\hline 21. I think drama lesson is not suitable for adult groups. & & .638 & & \\
\hline 40. I think drama lesson does not contribute to my moral development. & & .606 & & \\
\hline 3. I see drama lesson as timewasting. & & .599 & & \\
\hline 36. I see having much information about drama lesson as unnecessary. & & .576 & & \\
\hline 11. I do not believe drama lesson contribute to my social sensitivity. & & .563 & & \\
\hline 19. Drama lesson is one of the least important lessons for me. & & .562 & & \\
\hline 33. Increasing drama lessons numerically makes me happy. & & & 729 & \\
\hline 4. I do my drama lesson homework in pleasure. & & & 683 & \\
\hline 13. I want drama activities take much longer. & & & 678 & \\
\hline 35. I want to be a drama teacher in the future. & & & 619 & \\
\hline 18. I try to provide active participation in drama activities. & & & .587 & \\
\hline 10. I participate in drama activities voluntarily. & & & .554 & \\
\hline 39. I worry about having trouble in drama lesson. & & & & .787 \\
\hline 38. I do not think I fulfill drama lesson's necessities. & & & & .746 \\
\hline 30. I feel myself desperate in drama lessons. & & & & .683 \\
\hline 25. Taking part in drama lesson activities make me annoy. & & & & .563 \\
\hline
\end{tabular}


According to Table 2, it is seen that 31 items of scale were gathered in four factors. Item numbers which is involved in factors were determined as 13 in the first factor, as 8 in the second factor, as 6 in the third factor and as 4 in the fourth factor. When aforementioned factors are examined, the first factor was named as "Positive Attitude of Drama Lesson for Improving Personal and Professional Skills", the second factor was named as "Negative Attitude of Drama Lesson for Improving Personal and Professional Skills", the third factor was named as "Positive Attitude for Drama Lesson Activities" and the forth factor was named as "Negative Attitude for Drama Lesson Activities".

According to exploratory factor analysis in Table 2, items' load values in first factor show a change between .735 and .537 , items' load values in second factor show a change between .653 and .562 , items' load values in third factor show a change between .729 and .554 , items' load values in fourth factor show a change between .787 and .563 . In addition to this, when examined factors' variance percentages, it is seen that first factor explains $23,688 \%$ of variance by itself, second factor explains $15,023 \%$ of variance by itself, third factor explains $14,957 \%$ of variance by itself, fourth factor explains $10,165 \%$ of variance by itself. And it is seen that four factors explain $63,833 \%$ of total variance. Moreover, when examined eigenvalues that can give an idea about predicting importance level, it is seen that first factor's value is 7,343, second factor's value is 4,657, third factor's value is 4,637, and fourth factor's value is 3,151 . Load values regarding factors in scale can be seen in Table 3.

Table 3. Load values regarding factors in scale

\begin{tabular}{ccc}
\hline Factors & Eigenvalues & Stated Variance Percentage (\%) \\
\hline F1 & 7,343 & 23,68 \\
F2 & 4,657 & 15,02 \\
F3 & 4,637 & 14,95 \\
F4 & 3,151 & 10,16 \\
\hline
\end{tabular}

F1: Load values of first factor

F2: Load values of second factor

F3: Load values of third factor

F4: Load values of fourth factor

Results obtained by exploratory factor analysis were tried to verify the structure by testing with confirmatory factor analysis. It can be seen data regarding confirmatory factor analysis in Figure 2.

In Figure 2, it can be seen that error variances of items and load values of factors related to items regarding the structure that was obtained via confirmatory factor analysis. And it can be seen that when examined the relation values of items with factors, correlations vary between .63 and 1.00. Moreover, when examined relation values between factors, it is seen that correlations vary between .71 and .83 . As a result of confirmatory factor analysis of model, Chi-square $\left(\chi^{2}\right)$ value is 942.14 , degree of freedom ( $\mathrm{df}$ ) is $428, \mathrm{p}=.000$ and Root-Mean-Square Error of Approximation (RMSEA) is 0.068. In accordance with these obtained information, it can be said that scale's items are suitable in terms of representativeness of structure. 


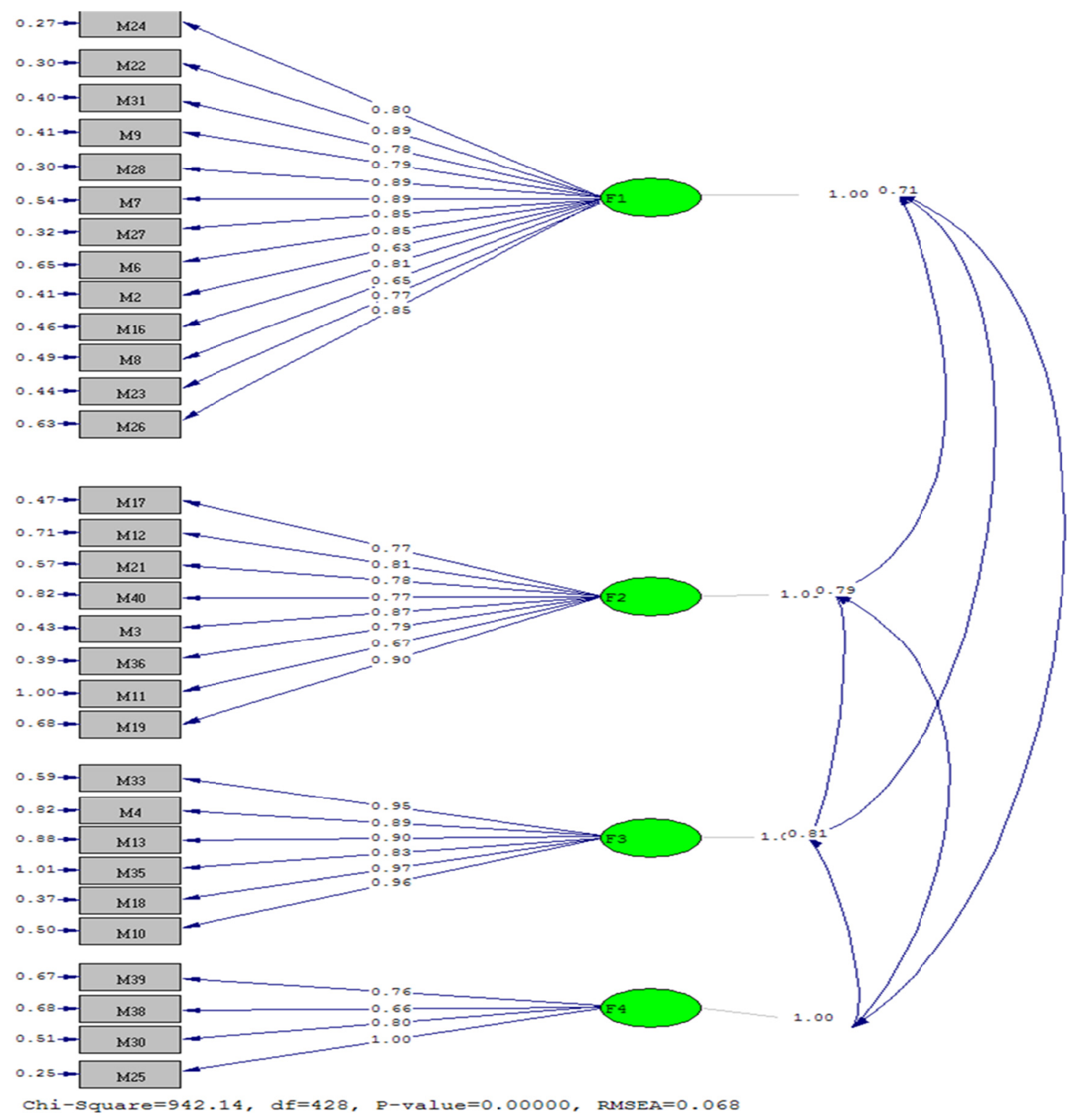

Figure 2. Data regarding confirmatory factor analysis

\subsection{Findings Regarding Reliability}

Cronbach Alpha $(\mathrm{Cr} \alpha)$ internal consistency coefficient was calculated so as to provide reliability in scale's development process. As a result of analysis, all Cronbach Alpha $(\mathrm{Cr} \alpha)$ values of scale were found as .965 . For the first factor of scale, Cronbach Alpha $(\mathrm{Cr} \alpha)$ coefficient of "Positive Attitude of Drama Lesson for Improving Personal and Professional Skills" was found as .950; for the second factor, Cronbach Alpha (Cr $\alpha$ ) coefficient of "Negative Attitude of Drama Lesson for Improving Personal and Professional Skills" was found as .888; for the third factor, Cronbach Alpha (Cr $\alpha)$ coefficient of "Positive Attitude towards Drama Lesson Activities" was found as .880 and for the fourth factor, Cronbach Alpha (Cr $\alpha$ ) coefficient of "Negative Attitude towards Drama Lesson Activities" was found as .836. In accordance with these obtained values, it can be said that the scale is reliable sufficiently.

\section{Discussion}

As a result of implemented factor analysis on scale items, 9 items $(1,5,14,15,20,29,32,34,37)$ which were not suitable for scale's structure and loaded more than one dimension were removed from scale and it was continued with remaining 31 items. As a result of analysis, KMO value was calculated as .963. Moreover, it was reached a finding that chi-square statistic test values, which was obtained as a result of Bartlett Sphericity test, were significant $\left(\chi^{2}=5738.89\right.$, $\mathrm{df}=465, \mathrm{p}=0.000$ ). Factor analyses were made by using varimax method of vertical rotation methods and factor loads lower cut-off point was taken as .45. It is seen that 31 scale items were gathered in four factors. Item numbers which is involved in factors were determined as 13 in the first factor, as 8 in the second factor, as 6 in the third factor and as 4 in the fourth factor. 
Results obtained by exploratory factor analyses were tried to verify the structure by testing with confirmatory factor analysis. Correlation values of factor relations of items vary between .63 and 1.00 . Moreover, correlation values of inter-factor relations vary between .71 and .83 . As a result of confirmatory factor analysis of model, Chi-square $\left(\chi^{2}\right)$ value was found as 942.14, degree of freedom (df) was 428, p=.000 and Root-Mean-Square Error of Approximation (RMSEA) was 0.068. So as to provide reliability in scale's development process, Cronbach Alpha (Cr $\alpha$ ) internal consistency coefficient was calculated. As results of analyses, all Cronbach Alpha $(\mathrm{Cr} \alpha)$ values of scale were found as .965 .

\section{Conclusions and Suggestions}

Drama was often discussed as a method in studies and effectiveness of this method on students' achievements, attitudes and interests was examined. In addition to that, pre-service teachers' attitudes towards drama and self-sufficiency for using drama method were studied. When looked to studies for pre-service teachers' attitudes towards drama lesson, Şahin (2010) examined pre-service class teachers' attitudes towards drama lesson and used "Attitude Scale for Creative Drama Lesson”, which was developed by Adıgüzel (2006), as data collection tool in his study. Likewise, Ünal (2004) examined pre-service class teachers' attitudes towards drama lesson in primary education and used "Attitude Scale for Drama Lesson in Primary Education", which was developed by himself as data collection tool in his study.

Ceylan \& Ömeroğlu (2011) developed "Assessment Scale towards Drama in Preschool Education” within the scope of scale development studies to assess pre-service preschool teachers' attitudes about drama training. Başçı \& Gündoğdu (2011) found out pre-service teachers' attitudes and opinions towards drama lesson and used "Attitude Scale for Creative Drama Lesson", which was developed by Adıgüzel (2006), as data collection tool in his study. When looked to these studies, Ceylan \& Ömeroğlu (2011) and Ünal (2004) developed respectively "Attitude Scale for Pre-service Preschool Teacher and Class Teachers". These developed scales do not include all pre-service teachers. It was discussed only drama in "Attitude Scale for Creative Drama Lesson", which was developed by Adıgüzel (2006) for all pre-service teachers.

In this study, drama lesson was examined with a general approach and it includes not only creative drama but also educational drama as well. If pre-service teacher have positive attitude towards this lesson, they will probably use drama method in class in their teaching life. In this study, pre-service teachers' attitudes towards drama lesson can be found out with developed scale and in accordance with the results, it can be made arrangements about drama lessons in faculty of education in universities.

\section{References}

Adıgüzel, H. Ö. (2006). The concept, components and stages of creative drama. Journal of Creative Drama, 1, 17-27.

Akınoğlu, O., \& Akbaş, H. Ş. (2010). The impact of drama practices as a problem-solving strategies in science education on conceptual understanding. International Conference on New Trends in Education and Their Implications. 11-13 November, Antalya.

Altıkulaç, A., \& Akhan, N. E. (2010). The effect of using the creative drama method and the six thinking that technique on student success and attitudes in eighth-grade revolution History and Kemalism lesson. Ahi Evran University Journal of Kırşehir Education Faculty, 11(3), 225-247.

Andersen, C. (2004). Learning in "as-if" worlds: Cognition in drama in education. Theory into Practice, 43(4), 281-286. https://doi.org/10.1207/s15430421tip4304_6

Arslan, A., Şahin, A., Şahin, E., \& Akçay, A. (2011). Effect of creative drama method on 6th grade students' attitude towards Turkish course. Journal of National Education, 190, 234-247.

Avcioğlu, H. (2012). The effectiveness of the instructional programs based on cooperative learning and drama techniques in acquisition of social skills by the children with intellectual disabilities. Education and Science, 37(163), 110-125.

Aykaç, M., \& Adıgüzel, Ö. (2011). The effect of using creative drama as a method in social studies class on students' achievement. Kastamonu Education Journal, 19(1), 297-314.

Baldwin, P. (2009). School improvement through drama: A creative whole class, whole school approach. London: Network Continum.

Başc1, Z., \& Gündoğdu, K. (2011). The attitudes and opinions of prospective teachers related to drama course: The case of Atatürk University. Elementary Education Online, 10(2), 454-467.

Çam, F., Özkan, E., \& Avinç, İ. (2009). Comparative analyses of drama method in Science and Technology course in terms of academic achievement and attitude towards to lesson: Rural and urban school sample. Gazi University 
Journal of Gazi Educational Faculty, 29(2), 459-483.

Can, B., \& Cantürk-Günhan, B. (2009). The self-efficacy beliefs scale towards the using of creative drama method. e-Journal of New World Sciences Academy, 4(1), 34-43.

Çelen, İ., \& Akar-Vural, R. (2009). Drama in education and teaching English: A research on the fourth grade elementary students. Elementary Education Online, 8(2), 425-438.

Ceylan, Ş., \& Ömeroğlu, E. (2011). Developing the scale about drama education for attitudes evaluation of pre-school teacher candidate. Pamukkale University Journal of Education, 29, 15-26.

Cohen, L., Manion, L., \& Morrison, K. (2007). Research Methods in Education. New York: Routledge.

Crumpler, T., \& Schneider, J. J. (2002). Writing with their whole being: A cross study analysis of children's writing from classrooms using process drama. Research in Drama Education, 7(1), 61-79. https://doi.org/10.1080/13569780120113148

Dorion, K. R. (2009). Science through drama: A multiple case exploration of the characteristics of drama activities used in secondary science lessons. International Journal of Science Education, 31(16), 2247-2270. https://doi.org/10.1080/09500690802712699

Eagly, A. H., \& Chaiken, S. (1993). The psychology of attitudes. Fort Worth, Texas: Harcourt Brace Jovanovich College Publishers.

Fenli, A. (2010). The attitude of candidates of classroom teaching oriented to creative drama lesson (Sample of MAKU). Unpublished Master's Thesis. Mehmet Akif Ersoy University Institute of Social Sciences, Burdur.

Gomez, D. I. (2010). Using drama to improve oral skills in the ESL classroom. International Schools Journal, 30(1), 29-37.

Karadağ, E., Korkmaz, T. \& Çalışkan, N. (2007). The evaluation of the effectiveness of drama method in teaching of social science according to cognitive domain. Ahi Evran University Journal of Kirşehir Education Faculty, 8(1), 179-195.

Kim, J. R. (2011). Influence of teacher preparation programs on pre-service teachers' attitudes towards discussions. International Journal of Inclusive Education, 15(3), 355-377. https://doi.org/10.1080/13603110903030097

Kırmızı, F. S. (2007). The effect of creative drama technique on reading comprehension and students' opinions about the technique. Eurasian Journal of Educational Research (EJER), 29, 59-71.

Köseoğlu, İ., \& Ünlü, M. (2006). The implementation of the drama technique as teaching method in Geography lessons. Journal of Marmara Geographic, 13, 125-132.

Levitt, K. E. (2002). An analysis of elementary teachers' beliefs regarding the teaching and learning of science. Science Education, 86(1), 1-22. https://doi.org/10.1002/sce.1042

McNaughton, M. J. (2004). Educational dramas in the teaching of education for sustain ability. Environmental Education Research, 10(2), 139-155. https://doi.org/10.1080/13504620242000198140

Nicholls, J., \& Philip, R. (2012). Solo life to second life: The design of physical and virtual learning spaces inspired by the drama classroom. RIDE: The Journal of Applied Theatre and Performance, 17(4), 583-602. https://doi.org/10.1080/13569783.2012.727628

Oğur, B., \& Bağc1-Kılıç, G. (2005). The effect of drama integration into elementary science instruction on the students' success. Eurasian Journal of Educational Research (EJER), 20, 178-188.

Önder, A. (2001). Educational drama for learning by experience: Implementation techniques and examples of the theoretical basis. Istanbul: Epsilon.

Özbek, G., \& Baturay, M. H. (2009). Educating primary school students on computer usage ethics and health by the drama method. e-Journal of New World Sciences Academy, 4(3), 707-714.

Prendiville, F., \& Toye, N. (2007). Speaking and listening through drama 7-11. London: Paul Chapman Publishing.

San, İ. (1990). Creative drama in education. Ankara University Journal of Faculty of Educational Sciences, 23(2), 573-582.

Şimşek, T., Topal, Y., Maden, S., \& Şahin, A. (2010). Teaching of the topic determinant using dramatization method in Turkish lesson of primary second stage. Journal of National Education, 186, 106-120.

Taylor, P. (2000). The drama classroom: Action, reflection, transformation. London: Routledge Falmer. https://doi.org/10.4324/9780203209172 
Ünal, E. (2004). A study on the students' attitudes toward the lesson drama. Trakya University Journal of Social Science, 5(2), 1-15.

Wright, C., Diener, M. L., \& Kemp, J. L. (2013). Story telling dramas as a community building activity in an early childhood classroom. Early Childhood Education Journal, 41, 197-210.

https://doi.org/10.1007/s10643-012-0544-7

Yavuzer, Y. (2012). Effect of creative drama based group guidance on male-adolescents' conflict resolution skills. Eurasian Journal of Educational Research (EJER), 47, 113-130.

\section{Appendix A}

Attitude Scale towards Drama Lesson for Pre-service Teachers

There are some statements about drama lesson below. You are asked to indicate your contributory level for each statement. Please mark only one checkbox for each statement. After reading the statements, please mark the most suitable option with (X). Items are rated as Strongly Disagree (1), Disagree (2), Neutral (3), Agree (4) and Strongly Agree (5). Please do not leave any blank item.

Thank you for sparing time.

\begin{tabular}{|c|c|c|c|c|c|c|}
\hline$\stackrel{\ominus}{Z}$ & Items & 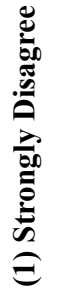 & 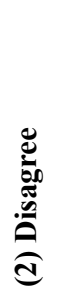 & 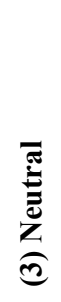 & 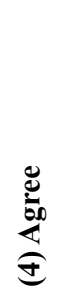 & 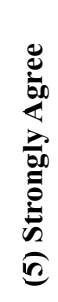 \\
\hline 1 & I think drama lesson affects my communication skill positively. & & & & & \\
\hline 2 & I see drama lesson as timewasting. & & & & & \\
\hline 3 & I do my drama lesson homework in pleasure. & & & & & \\
\hline 4 & I believe I know myself better thanks to drama lesson. & & & & & \\
\hline 5 & I think drama lesson will change my perspective on events. & & & & & \\
\hline 6 & I do not think drama lesson contributes to my professional ability. & & & & & \\
\hline 7 & I worry about having trouble in drama lesson. & & & & & \\
\hline 8 & I participate in drama activities voluntarily. & & & & & \\
\hline 9 & I do not believe drama lesson contribute to my social sensitivity. & & & & & \\
\hline 10 & I do not think drama lessons will improve my empathy ability. & & & & & \\
\hline 11 & I want drama activities take much longer. & & & & & \\
\hline 12 & I can control my emotions better thanks to drama lesson. & & & & & \\
\hline 13 & Drama lesson do not contribute to my education. & & & & & \\
\hline 15 & Drama lesson is one of the least important lessons for me. & & & & & \\
\hline 16 & I think drama lesson is not suitable for adult groups. & & & & & \\
\hline 17 & I think my self-confidence increases thanks to drama lessons. & & & & & \\
\hline 18 & I find drama lessons entertaining. & & & & & \\
\hline 19 & I believe drama lessons develop my imagination. & & & & & \\
\hline 20 & Taking part in drama lesson activities make me annoy. & & & & & \\
\hline 21 & I feel comforted after drama lessons. & & & & & \\
\hline 22 & I believe drama lesson will improve my creative ability. & & & & & \\
\hline 23 & I believe drama lesson improve my sense of responsibility. & & & & & \\
\hline 24 & I feel myself desperate in drama lessons. & & & & & \\
\hline 25 & I think I will improve my ability of making quick decision thanks to drama lesson. & & & & & \\
\hline 26 & Increasing drama lessons numerically makes me happy. & & & & & \\
\hline 27 & I want to be a drama teacher in the future. & & & & & \\
\hline 28 & I see having much information about drama lesson as unnecessary. & & & & & \\
\hline 29 & I do not think I fulfill drama lesson's necessities. & & & & & \\
\hline 30 & I believe drama lesson affects my comprehension skill positively. & & & & & \\
\hline 31 & I think drama lesson does not contribute to my moral development. & & & & & \\
\hline
\end{tabular}

This work is licensed under a Creative Commons Attribution 3.0 License. 